Simulation of groundwater age evolution during the Wisconsinian glaciation over the Canadian landscape

\author{
Journal Article \\ Author(s): \\ Lemieux, Jean-Michel; Sudicky, Edward A. \\ Publication date: \\ 2010 \\ Permanent link: \\ https://doi.org/10.3929/ethz-b-000017252
}

Rights / license:

In Copyright - Non-Commercial Use Permitted

Originally published in:

Environmental Fluid Mechanics 10(1-2), https://doi.org/10.1007/s10652-009-9142-7 


\title{
Simulation of groundwater age evolution during the Wisconsinian glaciation over the Canadian landscape
}

\author{
Jean-Michel Lemieux • Edward A. Sudicky
}

Received: 6 April 2009 / Accepted: 15 June 2009 / Published online: 10 July 2009

(C) Springer Science+Business Media B.V. 2009

\begin{abstract}
The simulation of groundwater age (residence time) is used to study the impact of the Wisconsinian glaciation on the Canadian continental groundwater flow system. Key processes related to coupled groundwater flow and glaciation modeling are included in the model such as density-dependent flow, hydromechanical loading, subglacial infiltration, glacial isostasy, and permafrost development. It is found that mean groundwater ages span over a large range in values, between zero and $42 \mathrm{Myr}$; exceedingly old groundwater is found at large depths where there is little groundwater flow because of low permeabilities and because of the presence of very dense brines. During the glacial cycle, old, deep groundwater below the ice sheet mixes with the young subglacial meltwater that infiltrates into the subsurface; the water displacement due to subglacial recharge reaches depths up to $3 \mathrm{~km}$. The depth of penetration of the meltwater is, however, strongly dependent on the permeability of the subsurface rocks, the presence of dense brines and the presence or absence on deep fractures or conductive faults. At the end of the simulation period, it was found that the mean groundwater age in regions affected by the ice sheet advance and retreat is younger than it was at the last interglacial period. This is also true for frozen groundwater in the permafrost area and suggests that significant parts of this water is of glacial origin. Finally, the simulation of groundwater age offers an alternative and pragmatic framework to understand groundwater flow during the Pleistocene and for paleo-hydrogeological studies because it records the history of the groundwater flow paths.
\end{abstract}

Keywords Groundwater age $\cdot$ Numerical modelling $\cdot$ Wisconsinian glaciation · Canada Paleo-hydrogeology

J.-M. Lemieux ( $\square)$

Geological Institute, ETH Zurich, 8092 Zurich, Switzerland

e-mail: jmlemieux@alumni.uwaterloo.ca

E. A. Sudicky

Department of Earth and Environmental Sciences, University of Waterloo, 200, University Avenue West, Waterloo, ON N2L 3G1, Canada

e-mail: sudicky@ sciborg.uwaterloo.ca 


\section{Introduction}

There are worldwide studies that have provided compelling evidence that significant volumes of Pleistocene waters (glacial meltwater from ice sheets or meteoric water), were driven into subsurface aquifers during past glaciation periods, and sometimes to great depths [11,1517,21,22,31,33,36,37,41,43-45,53,57]. As pointed out by Person et al. [37], the origin of Pleistocene waters in subsurface aquifers is important to study for several reasons. Pleistocene waters have geochemical properties that are different than autochthonous waters; their quality is usually good, and in some locations, they are an important source of freshwater $[16,53]$. Glacial meltwater is also associated with the generation of biogenic gas resources that are exploited by the petroleum industry in the Michigan and Illinois basins [33]. Moreover, the lowering of sea level related to the growth of ice sheets have exposed coastal aquifers to freshwater recharge such that, in some locations, the freashwater/sea water interface observed today is not in equilibrium with the current sea level $[1,36]$.

There are several studies that have attempted to quantify Pleistocene recharge rates and patterns using numerical models [5-10,23,34-40,54,57] because they are powerful tools that can take into account the numerous processes involved such as subglacial recharge, permafrost development, land surface isostatic evolution, mechanical loading, sea-level change, etc. However, in most cases, there is a paucity of data available for their calibration such that they are potentially unreliable. For this reason, most of these studies were conducted to explore alternative meltwater recharge scenarios to the groundwater system and to improve our understanding of the coupled processes involved. Potential datasets for the calibration of paleo-hydrogeological models include anomalous pressure measurements [e.g., 3,4], groundwater geochemistry [18], groundwater age estimates using environmental isotopes [15,32] and noble gas data $[2,25]$.

Here, we use groundwater age as a tracer to delineate groundwater recharge zones and groundwater flow paths during a full $120 \mathrm{kyr}$ glaciation cycle. Groundwater age, which can be defined as the time elapsed since the water infiltrated in a recharge zone, is a measure of the residence time of water in the subsurface and can be used to track the recharge history of an aquifer. The numerical model HydroGeoSphere [27,29,52] is used to simulate three-dimensional groundwater age evolution during the Wisconsinian glaciation over the Canadian landscape and up to a depth of $10 \mathrm{~km}$. The objective is to delineate the recharge history of glacial meltwater into the subsurface during the last glaciation period and to better understand the impact of glaciations on the evolution of deep groundwaters. Presently, there is a paucity of deep groundwater age measurements over the Canadian landscape, particularly in remote regions. We feel that our calculations could serve as a guide for selecting strategic locations for the collection of age data to further our model development.

\section{The computation of mean groundwater age}

Groundwater age is usually defined as the time elapsed since the water infiltrated in a recharge zone [12,20,24]. Each water molecule enters the subsurface at different times and a zero age is assigned to molecules that enter the system at the recharge boundaries.

Water that circulates in the subsurface will follow different flow paths depending on the spatial structure of the geologic materials and the boundary conditions. Some flow paths may be short and shallow, but others may produce deep circulation patterns in the subsurface that will require a long period of time before discharging to the surface. The length of the flow path and the time elapsed since the water entered the subsurface will also affect the water 
chemistry. Modelling groundwater age is then equivalent to simulating the advective and dispersive transport of conservative substances in groundwater. On the other hand, the age of a water sample is the average of all the water molecules collected in a sample, some of which may be from different origins. For this reason, groundwater age should also be viewed in a probabilistic framework rather than as a single value at each point in space and time. Cornaton and Perrochet [13] show, using a generalized reservoir theory, that the statistical distribution of the random variable groundwater "age" can be modelled using a formulation based on advective-dispersive transport of a conservative tracer, using appropriate boundary conditions. The transient age probability density function (PDF) is obtained for a finite reservoir, $\Omega$, by solving the boundary value problem:

$$
\frac{\partial \phi g_{A}}{\partial t}=-\nabla \cdot \mathbf{q} g_{A}+\nabla \cdot \phi \mathbf{D} \nabla g_{A}+q_{I} \delta(\tau)-q_{O} g_{A}
$$

in which:

$$
\begin{aligned}
g_{A}(\mathbf{x}, 0, \tau) & =f(\mathbf{x}, \tau) \quad \text { in } \Omega, \\
\mathbf{J}_{A}(\mathbf{x}, t, \tau) \cdot \mathbf{n} & =(\mathbf{q} \cdot \mathbf{n}) \delta(\tau) \quad \text { on } \Gamma_{-}
\end{aligned}
$$

where $g_{A}(x, t, \tau)$ is the transported transient age PDF, with $t$ being the clock-time, $\tau$ the age dimension, $\phi$ is porosity or mobile water content, $\mathbf{q}$ is the fluid flux vector, $\mathbf{D}$ is the macrodispersion tensor, $\mathbf{J}_{A}(x, t)$ is the total age mass flux vector, $\mathbf{x}=(x, y, z)$ is the vector of Cartesian coordinates, $\mathbf{n}$ is a normal outward unit vector, and $\delta$ is the Dirac delta function which ensures an impulse flux on $\Gamma_{-} . \Gamma_{-}$represents the inlet boundaries and $\Gamma_{+}$refers to the outlet boundaries. The terms $q_{I}$ and $q_{O}$ represent fluid sources and sinks, respectively, such as the internal production or extraction of groundwater. The total age mass flux vector $\mathbf{J}_{A}(x, t, \tau)$ is defined by the sum of the advective and dispersive age fluxes:

$$
\mathbf{J}_{A}(\mathbf{x}, t, \tau)=\mathbf{q} g_{A}(\mathbf{x}, t, \tau)-\phi \mathbf{D} \nabla g_{A}(\mathbf{x}, t, \tau)
$$

Equation 1 is a 5-D equation close to the one introduced by Delhez et al. [14] in the context of the theory of the age in ocean modelling. It however differs from Delhez et al.'s model by a porosity term required in the subsurface context.

The mean value $a(\mathbf{x}, t)$ of the probability density function $g_{A}(x, t, \tau)$ is defined by its first temporal moment:

$$
a(\mathbf{x}, t)=\int_{0}^{+\infty} u g_{A}(\mathbf{x}, t, u) d u
$$

where $u$ is the age value.

The first moment form of Eq. 1 is the mean age transport equation in which the mean age is defined as the average over a water sample containing water molecules having a range of individual ages. It is given by:

$$
-\nabla \cdot \mathbf{q} a+\nabla \cdot \phi \mathbf{D} \nabla a-q_{O} a+\phi=\frac{\partial \phi a}{\partial t} \text { in } \Omega
$$

which is equivalent to that obtained by Goode [20] with a mass conservation approach. The mean groundwater age can be computed by prescribing a "concentration" input that is proportional to the water flux at the inflow boundaries. Equation 6 can be solved by assigning $a(\mathbf{x}, t)=0$ on the inlet limits. Mean age is continuously generated during groundwater flow, since porosity acts as a source term. This source term indicates that groundwater is aging at the rate of one unit per unit time, on average. Cornaton and Perrochet [13] show that 
mean age computations using Eq. 6 are well-suited for simulating isotopic age dates. The implementation of mean age calculations is straightforward in a numerical model that already solves the advection-dispersion equation because only a source term that equals the porosity needs to be included $[13,56]$, as well as the use of proper boundary conditions $(a(\mathbf{x}, t)=0$ on $\left.\Gamma_{-}\right)$.

\section{Numerical model}

The numerical model HydroGeoSphere [52] is used to solve the density-dependant groundwater flow equation along with the advective-dispersive solute transport of total dissolved solids (TDS) and mean groundwater age (Eq. 6). Key processes pertaining to groundwater flow modelling during a glaciation period such as hydromechanical loading, subglacial infiltration, isostasy, sea-level change and permafrost development are also included in the model (see $[29,30]$ for details).

The limits of the model encompass the entire Canadian landscape as well as northern United States and Alaska; they were chosen to capture the entire region affected by the last glaciation and are sufficiently large such that the ice-sheet impact is negligible at the margins of the model (Fig. 1). Brick elements $(25 \times 25 \mathrm{~km})$ are used to discretize the three-dimensional

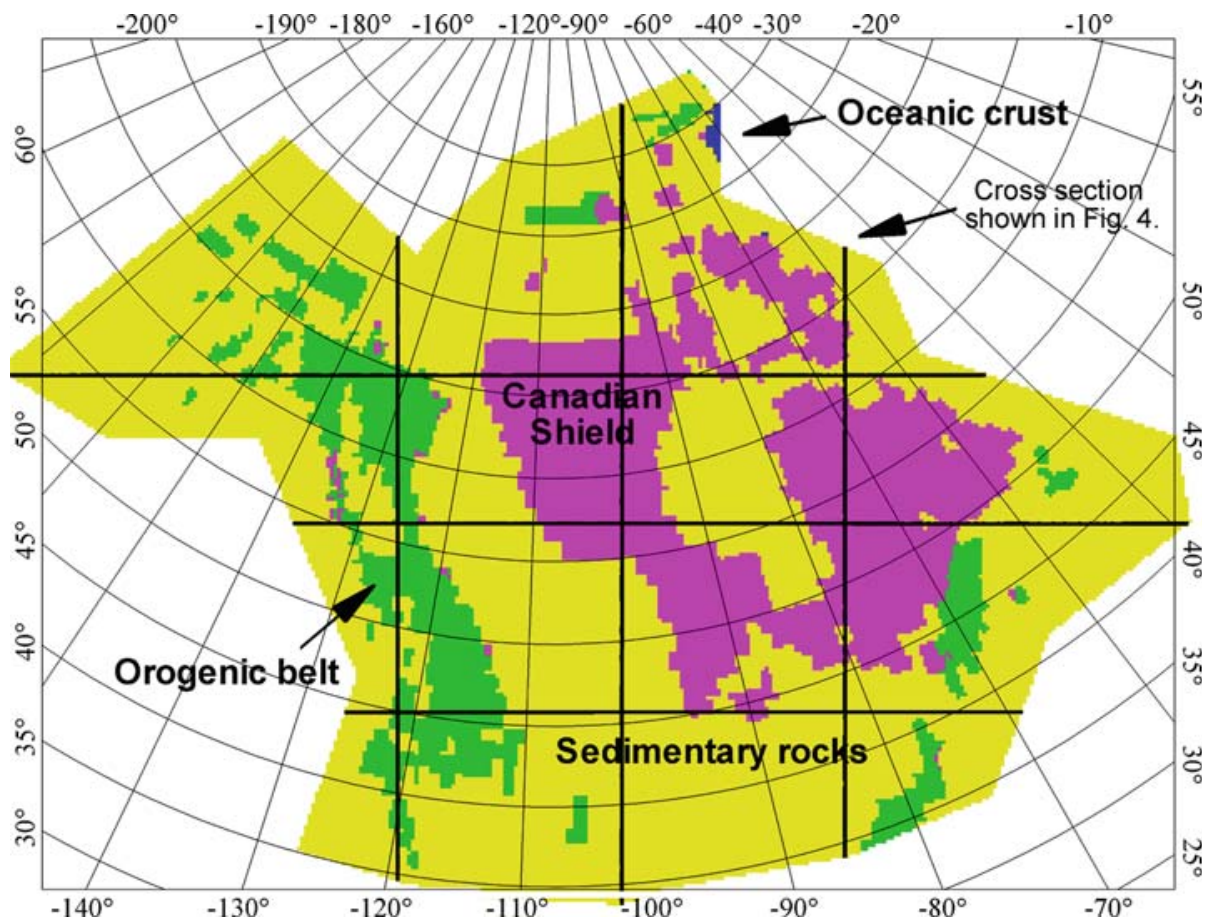

Fig. 1 Limits and hydrogeologic units of the numerical model. The geographic limits of the model are $172.5^{\circ}$ $\mathrm{W}$ and $42.5^{\circ} \mathrm{W}$ on the western and eastern boundaries and $34.75^{\circ} \mathrm{N}$ and $84.75^{\circ} \mathrm{N}$ on the southern and northern boundaries. Simplified bedrock geology facies used in the numerical model shown in pink: Canadian Shield, dark green: orogenic belts, dark blue: oceanic crust and yellow: sedimentary rocks (Constructed from [26] and [58]). The north-south and east-west black lines indicate the location of cross sections shown in Fig. 2. Albers equal-area map projection 
Table 1 Bedrock hydraulic properties by facies

\begin{tabular}{lllll}
\hline Parameter & Facies & & \\
\cline { 2 - 5 } & Sedimentary & Shield & Orogen & Oceanic crust \\
\hline$K$ (isotropic) (m/year) & 60.0 & 30.0 & 3.0 & 0.1 \\
Specific storage, $S_{S}\left(\mathrm{~m}^{-1}\right)$ & $5.0 \times 10^{-5}$ & $3.0 \times 10^{-6}$ & $1.0 \times 10^{-5}$ & $1.0 \times 10^{-5}$ \\
Porosity, $\phi(-)$ & 0.2 & 0.001 & 0.05 & 0.01 \\
Loading efficiency, $\zeta(-)$ & 0.2 & 0.2 & 0.2 & 0.2 \\
Longitudinal dispersivity, $\alpha_{L}(\mathrm{~m})$ & 5000 & 5000 & 5000 & 5000 \\
Transverse dispersivity, $\alpha_{T}(\mathrm{~m})$ & 100 & 100 & 100 & 100 \\
Transverse vertical dispersivity, $\alpha_{V}(\mathrm{~m})$ & 100 & 100 & 100 & 100 \\
Rock-water mass transfer constant, & $2.3 \times 10^{-7}$ & $2.3 \times 10^{-8}$ & $2.3 \times 10^{-8}$ & $2.3 \times 10^{-9}$ \\
$K_{m t}\left(\right.$ year $\left.^{-1}\right)$ & & & & \\
\hline
\end{tabular}

model (see [28] for discretization details) which covers about $10,000 \mathrm{~km} \times 6000 \mathrm{~km} \times 10$ $\mathrm{km}$ with a total $2 \mathrm{D}$ area of $2.5 \times 10^{7} \mathrm{~km}^{2}$. There are 10 elements in the vertical dimension and the elements size is between $70 \mathrm{~m}$ near the surface to $1 \mathrm{~km}$ at the bottom of the model.

Hydraulic properties are assigned according to the main bedrock geological units which, at the scale of the Canadian landscape, are simplified into four major facies (see Fig. 1; Table 1). Although this simplification is dramatic, computational constraints, the highly complex three-dimensional architecture of Canadian geology and the lack of systematic hydraulic measurements over the Canadian landscape limit the use of a highly-detailed geological model. The hydrogeological units are: Canadian Shield, Sedimentary basins, Orogenic belts and Ocean crust for which average hydrogeological properties based upon a review of the Canadian hydrogeology are assigned (see Table 1 and [30]).

Boundary conditions used here are inferred from the ice and climatic chronologies during the Wisconsinian glaciation derived from the Memorial University of Newfoundland/University of Toronto Glacial System Model [48-51], as described in Lemieux et al. [28].

A steady-state simulation is first performed to obtain a set of initial conditions for the transient simulation of groundwater flow, solute transport and groundwater age evolution during the last glacial cycle. The transient simulation starts at the last interglacial (LIG), $-120 \mathrm{kyr}$, until present time, $0 \mathrm{kyr}$, with a $0.1 \mathrm{kyr}$ timestep. Flow boundary conditions are updated every timestep and the age boundary condition is a specified zero age at inflow nodes, both in the subglacial and periglacial environments.

\section{Results}

\subsection{Mean groundwater age distribution at last interglacial}

In order to perform the age calculation during the last glacial cycle, initial conditions are needed for the age distribution at LIG. In order to obtain the mean groundwater age distribution at LIG, a steady-state flow field is obtained using the climatic conditions of the LIG (see [30] for details) for which a steady-state age transport simulation is performed. The age transport boundary condition consist of a specified zero age at inflow nodes and a zero-order source term equal to the porosity for each of the rock facies is used. Although it was recognized by Lemieux et al. [30] that interglacial groundwater flow systems may not 


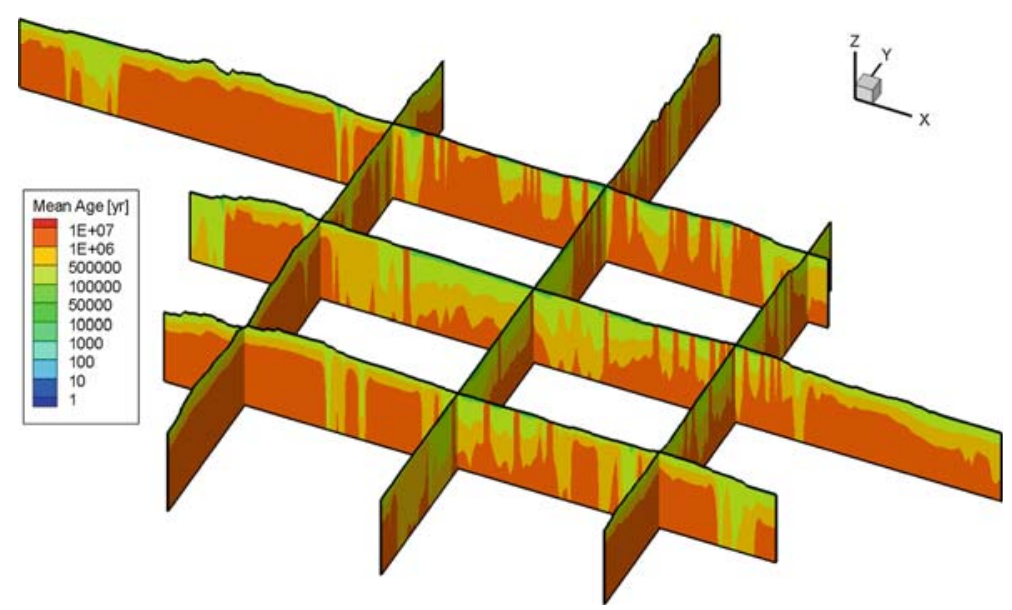

Fig. 2 Mean steady-state groundwater age distribution along selected cross sections for the last interglacial. The lateral extent of the figure is about $10,000 \mathrm{~km} \times 6000 \mathrm{~km}$. Vertical exaggeration is $60 \times$

be in equilibrium with interglacial boundary conditions, it is believed that this assumption is suitable for the exploratory nature of this study. The simulation of several prior glacial cycles to establish a dynamic equilibrium over that last several glacial cycles would have been the most suited approach, but the computational efforts were preclusive.

The calculated three-dimensional mean groundwater age pattern at LIG is shown in Fig. 2 along select cross sections. A clear pattern appears where the mean groundwater age at LIG is younger near the surface and older with depth. The mean groundwater ages span a very large range in values, ranging from zero to $42 \mathrm{Myr}$. A value of $42 \mathrm{Myr}$ occurs at great depth where there is little groundwater flow. Inspection of the results along the cross sections (Fig. 2) reveals that the youngest water occupies a relatively thin veneer near the surface. Because of the large density of the groundwater at depth, where there is little flow, a large mass of essentially stagnant groundwater exists in the bottom portion of the model.

The surface distribution of the mean groundwater age shows that most of the shallow water has a young age, which suggest that water has recently entered the system. A few locations, mainly along the coast of the province of Québec, Baffin Island and the north shore of Nunavut, show older water. They represent groundwater discharge regions and the age at the outlet is a mixture of deep old water and shallow, younger water. Such occurrences have been documented within the Canadian Shield $[19,42]$ and is usually associated with rapid discharge of deep groundwater along fractures. Although there are no explicit fractures in our model, fractures may only have enhanced the natural discharge of deep brines that we observe in our simulation results.

\subsection{Mean groundwater age evolution during the wisconsinian glaciation}

Figure 3 shows the simulated hydraulic head and groundwater age at different depths $z$ along with boundary conditions and climatic conditions applied on the surface over the glacial cycle at an observation point located in Timmins, Ontario. In Fig. 3a, subglacial conditions prevail above the horizontal line separating subglacial and periglacial conditions, while periglacial conditions prevail below. The black infilled region indicates that the subsurface is frozen and an unfilled box indicates frost-free conditions. For subglacial conditions, the the ice sheet 

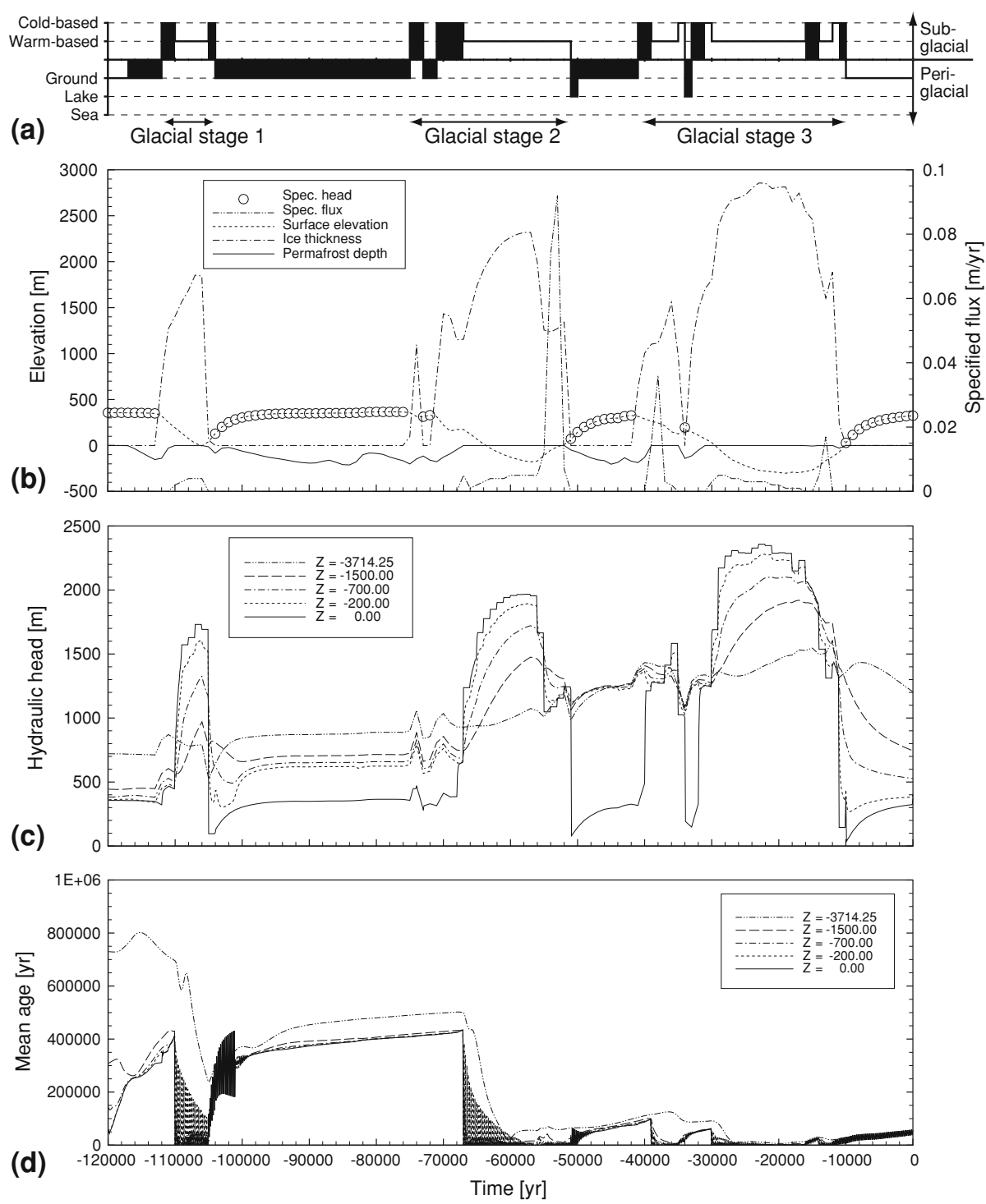

Fig. 3 Observation point located at Timmins, Ontario, Canada, showing (a) surface climatic conditions, (b) surface boundary conditions, (c) simulated hydraulic heads and (d) simulated mean age evolution for different depths (z). In (a) subglacial conditions prevail above the horizontal line while periglacial conditions prevail below. Black infill indicates frozen ground and white infill indicates frost-free conditions. For subglacial conditions, the bottom of the ice sheet can be warm-based or cold based. For periglacial conditions, the water table can be at ground surface level, at a periglacial/proglacial lake level or at sea level

can be warm-based, meaning there is subglacial melting, or cold based, meaning there is no subglacial melting. For periglacial conditions, the water table is either at ground surface level, at a periglacial/proglacial lake level or at sea level.

In Fig. 3b, the "elevation" axis on the left is used to designate the value of several variables such as specified hydraulic head and permafrost depth. Other variables displayed are the 
ground surface elevation and ice-sheet thickness. The summation of the ice-sheet thickness and the ground surface elevation gives the ice-sheet surface elevation. Permafrost thicknesses are shown as negative values to symbolize there are progressing downward into the ground. The summation of the surface elevation and the permafrost thickness provides the elevation of the lower limit of the permafrost. Specified heads are designated using discrete symbols when this boundary condition is active in the model. A specified water flux, using values corresponding to the axis on the right, is prescribed when the specified head boundary condition is inactive and subglacial meltwater is being produced.

In Figs. 3a and b, it can be seen that there were three glacial stages within the last glacial cycle. At the beginning of every glacial stage, the ice-sheet flows southward from the Arctic and cold temperatures associated with the climate evolution causes freezing of the ground such that thick permafrost develops (see $[28,30]$ for details). As the ice sheet flows, it covers the frozen ground and isolate it from the cold air temperature. The upward geothermal energy migration and frictional heat at the bottom of the ice sheet contribute to the melting of the subglacial permafrost and subglacial meltwater can be driven into the subsurface at great depths under ice-sheet pressure. This can be seen in Fig. 3c where subglacial simulated hydraulic heads increase up to $3 \mathrm{~km}$ when the ice sheet overrides the ground surface. A portion of the pore pressure increase is due to the subglacial meltwater recharge and a part is due to the surface loading of the km-thick ice sheet.

The groundwater age evolution is intimately related to the recharge of meltwater into the subsurface. It can be seen in Fig. 3d that the groundwater age decreases significantly, and up to $3 \mathrm{~km}$, when a large recharge event occurs, such as during glacial stage 3 . As the glacial period ends and time progresses towards present day, the groundwater age increases steadily due to the lack of mixing with young water derived from the meltwater. At the end of the simulation, the groundwater age is far from its initial values, especially at great depths. It should be noted that subglacial meltwater does not circulate to a depth of $3 \mathrm{~km}$, but displaces water up to this depth, depending on local rock permeabilities, which modifies the groundwater age.

Figures $4 \mathrm{a}-\mathrm{e}$ show the mean groundwater age distribution and permafrost depth along the eastern north-south cross section shown in Fig. 1. It can be seen that the initial mean age (at $t=-120 \mathrm{kyr}$ ) is very old at depth and becomes younger near the surface, where transit times are shorter. When the ice sheet grows, at $-30 \mathrm{kyr}$, large volumes of the subglacial meltwater mix with the old groundwater such that the mean groundwater age becomes younger. The mixing below the ice sheet occurs at great depths, and locations where the mean groundwater age was originally older than about $1 \mathrm{Myr}$ now has a value between $10 \mathrm{kyr}$ and $100 \mathrm{kyr}$. A thin veneer of young meltwater is clearly evident below the ice sheet at and following LGM. At the end of the simulation period, it can be seen that mean groundwater ages below regions that were affected by the ice sheet advance and retreat are much younger than they were at LIG.

The results also show that current frozen water within the permafrost area (Fig. 4e) is much younger than at LIG (Fig. 4a). This suggest that a large proportion of this frozen water is composed of subglacial meltwater infiltrated during the advance of the ice sheet and that the geochemical signature of the permafrost should point toward a glacial origin. A geochemical study conducted at the Lupin Mine (NWT, Canada) in a $500 \mathrm{~m}$ thick permafrost environment $[46,47]$ was, however, not able to unequivocally confirm this finding.

Finally, it should be noted that little numerical oscillations were observed during the simulation of the large subglacial recharge events (see Fig. 3d), but the overall stability of the model was satisfactory and converging rapidly at every timestep [30]. 

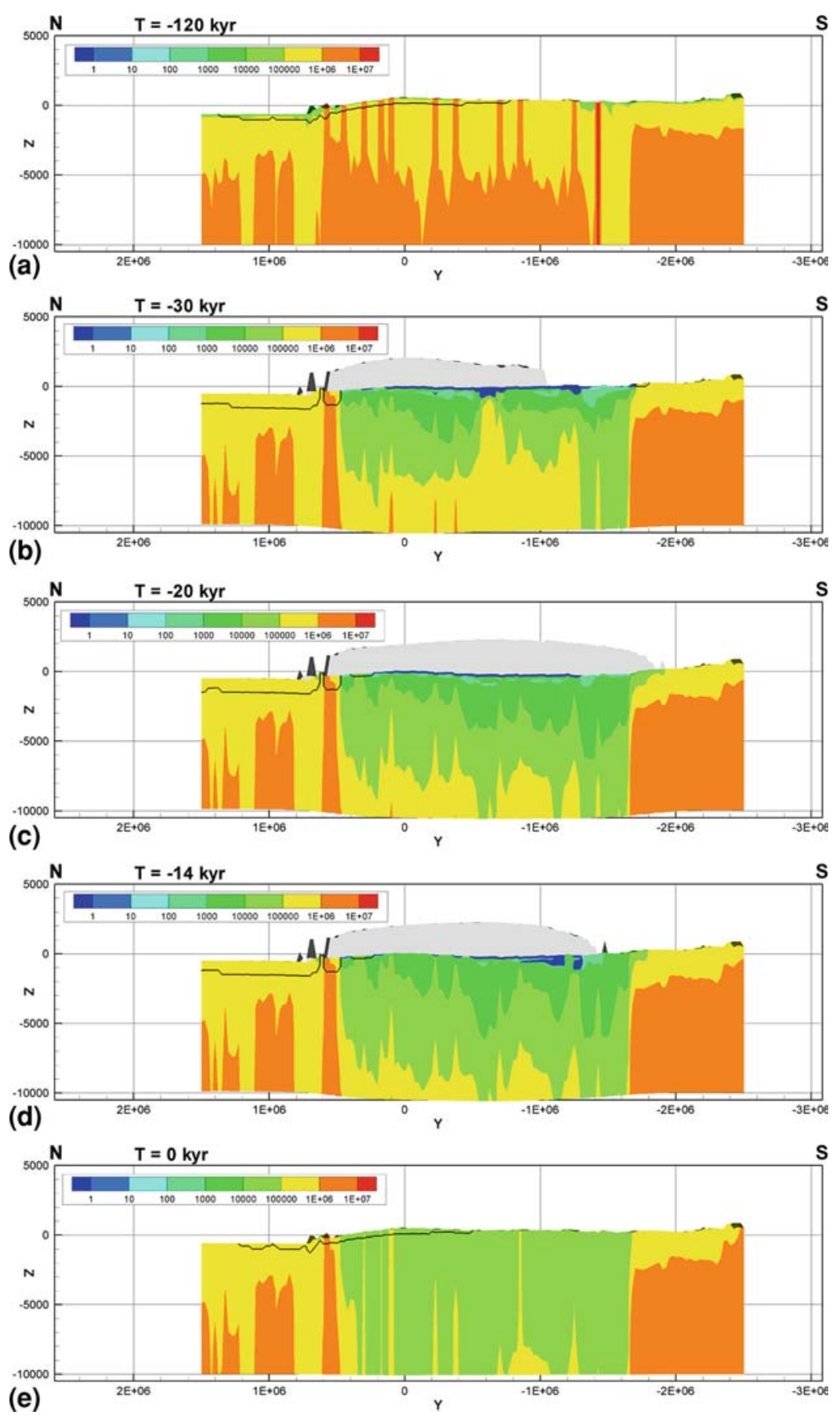

Fig. 4 Mean groundwater age and permafrost depth (solid line) along a selected north-south cross section (shown on Fig. 1) at selected time slices: $\mathbf{a}-120 \mathrm{kyr}$; b $-30 \mathrm{kyr}$; $\mathbf{c}-20 \mathrm{kyr}$; d $-14 \mathrm{kyr}$ and e $0 \mathrm{kyr}$. Vertical exaggeration: $100 \times$ 


\section{Conclusions}

Numerical simulation of groundwater flow is a powerful tool in order to understand the impact of past climates on groundwater resources. In this paper, the concept of groundwater age was applied to compute mean groundwater ages across the Canadian landscape at LIG and throughout the last glacial cycle. It was found that at LIG, mean groundwater ages are younger near the surface and become much older with depth. The mean groundwater ages span over a large range in values, between zero and $42 \mathrm{Myr}$. Exceedingly old groundwater is found at large depths where there is little groundwater flow because of low permeabilities and because of the presence of very dense brines.

During the glacial cycle, old, deep groundwater below the ice sheet mixes with the young subglacial meltwater that infiltrates into the subsurface and the resulting mean groundwater age becomes younger. Our calculations indicate that glacial meltwaters may have penetrated to to depths as large as one kilometer; however, this is based on a gross regionalization of the subsurface hydrogeology. These calculations are however in agreement with meltwater penetration depths observed in the Illinois, Michigan and Williston basins [22,31,37] and in the Canadian Shield $[11,15,41]$. They also agree with age estimates reported by McIntosh and Walter [32] in the Great Lake region, which extends up to $50 \mathrm{kyr}$. Although not presented here (see [30]), simulated total dissolved solids profiles in the Canadian Shield also agree with reported measurements of Frape and Fritz [18].

Clearly, local-scale analysis which bring to bear local geological conditions would serve to refine our calculations. Nevertheless, the work presented here can serve as a framework to refine such calculations and can be useful for choosing potential field sampling locations for further study, sitting of nuclear waste repositories, and identify potential reservoirs of high-quality drinking water.

Acknowledgments Financial support for this study was provided by the Natural Sciences and Engineering Research Council of Canada (NSERC) and the Ontario Graduate Scholarship (OGS) Program as scholarships to J.-M. Lemieux and also from NSERC and the Canada Research Chairs program as research funding to E.A. Sudicky. We would like to thank guest-editor Fabien Cornaton for insightful comments on groundwater age simulation along with two anonymous reviewers who provided constructive comments on the original manuscript.

\section{References}

1. Akouvi A, Dray M, Violette S, de Marsily G, Zupp GM (2008) The sedimentary coastal basin of Togo: example of a multilayered aquifer still influenced by a palaeo-seawater intrusion. Hydrogeol J 16(3): 419-436. doi:10.1007/s10040-007-0246-1

2. Andrews JN, Lee DJ (1979) Inert gases in groundwater from the Bunter sandstone of England as indicators of age and palaeoclimatic trends. J Hydrol 41:233-252

3. Bahr JM, Moline GR, Nadon G (1994) Anomalous pressures in the deep Michigan Basin. In: Ortoleva P (ed) Basin compartments and seals, AAPG Memoir 61, AAPG, pp 153-165

4. Bekele EB, Rostron BJ, Person MA (2003) Fluid pressure implications of erosion unloading, basin hydrodynamics and glaciation in the Alberta Basin. J Geochem Explor 78(79):143-147

5. Bense VF, Person MA (2008) Transient hydrodynamics within inter-cratonic sedimentary basins during glacial cycles. J Geophys Res 113:F04005. doi:10.1029/2007JF000969

6. Boulton GS, Slot T, Blessing K, Glasbergen P, Leijnse T, van Gijssel K (1993) Deep circulation of groundwater in overpressured subglacial aquifers and it's geological consequences. Quat Sci Rev 12:739-745

7. Boulton GS, Caban PB, van Gijssel K (1995) Groundwater flow beneath ice sheets: Part I - Large scale patterns. Quat Sci Rev 14:545-562

8. Boulton GS, Caban PB, van Gissel K, Leijnse A, Punkari M, van Weert FHA (1996) The impact of glaciation on the groundwater regime of Northwest Europe. Global Planet Change 12(1-4):397-413 
9. Breemer CH, Clark PU, Haggerty R (2002) Modeling the subglacial hydrology of the late Pleistocene Lake Michigan Lobe, Laurentide Ice Sheet. Geol Soc Am Bull 114(6):665-674

10. Chan T, Christiansson R, Boulton GS, Ericsson LO, Hartikainen J, Jensen MR, Ivars DM, Stanchell FW, Vistrand P, Wallroth T (2005) DECOVALEX III BMT3/BENCHPAR WP4, the thermo-hydro-mechanical responses to a glacial cycle and their potential implications for deep geological disposal of nuclear fuel waste in a fractured crystalline rock mass. Int J Rock Mech Min 42(5-6):805-827

11. Clark ID, Douglas M, Raven K, Bottomley D (2000) Recharge and preservation of Laurentide glacial melt water in the Canadian Shield. Ground Water 38(5):735-742

12. Cornaton $\mathrm{F}$ (2004) Deterministic models of groundwater age, life expectancy and transit time distributions in advective-dispersive systems. PhD thesis, University of Neuchâtel, Switzerland

13. Cornaton F, Perrochet P (2006) Groundwater age, life expectancy and transit time distributions in advectivef́bdispersive systems: 1. Generalized reservoir theory. Adv Water Resour 29(9):1267-1291

14. Delhez EJM, Campin JM, Hirst AC, Deleersnijder E (1999) Toward a general theory of the age in ocean modelling. Ocean Modelling 1:17-27

15. Douglas M, Clark ID, Raven K, Bottomley D (2000) Groundwater mixing dynamics at a Canadian Shield mine. J Hydrol 235(1-2):88-103

16. Edmunds WM (2001) Paleowaters in European coastal aquifers-the goals and main conclusions of the PALAEAUX project. In: Edmunds WM, Milne CJ (eds) Paleowaters in coastal Europe: evolution of groundwater since the late Pleistocene, Geological Society, London, pp 1-16, Special Publications, 189

17. Ferguson GAG, Betcher RN, Grasby SE (2007) Hydrogeology of the Winnipeg formation in Manitoba, Canada. Hydrogeol J 15: 573-587. doi:10.1007/s10040-006-0130-4

18. Frape SK, Fritz P (1987) Geochemical trends for groundwaters from the Canadian Shield. In: Fritz P, Frape SK (eds) Saline water and gases in crystalline rocks, Geological Association of Canada Special paper 33, pp 19-38

19. Gascoyne M, Sheppard MI (1993) Evidence of terrestrial discharge of deep groundwater on the Canadian Shield from Helium in soil gases. Environ Sci Technol 27(12):2420-2426

20. Goode DJ (1996) Direct simulation of groundwater age. Water Resour Res 32(2):289-296

21. Grasby SE, Chen Z (2005) Subglacial recharge into the western Canada sedimentary basin-impact of Pleistocene glaciation on basin hydrodynamics. Geol Soc Am Bull 117(3/4):500-514

22. Grasby S, Osadetz K, Betcher R, Render F (2000) Reversal of the regional-scale flow system of the Williston basin in response to Pleistocene glaciation. Geology 28(7):635-638

23. Hoaglund JRIII, Kolak JJ, Long DT, Larson GJ (2004) Analysis of modern and Pleistocene hydrologic exchange between Saginaw Bay (Lake Huron) and the Saginaw Lowlands area. Geol Soc Am Bull 116(1-2): 3-15

24. Kazemi GA, Lehr JH, Perrochet P (2006) Groundwater age. Wiley, Hoboken

25. Klump S, Grundl T, Purtschert R, Kipfer R (2008) Groundwater and climate dynamics derived from noble gas, ${ }^{14} \mathrm{C}$, and stable isotope data. Geology 36(5):395-398

26. Laske G, Masters G (1997) A global digital map of sediment thickness. EOS Trans AGU 78:F483

27. Lemieux JM (2006) Impact of the Wisconsinian glaciation on Canadian continental groundwater flow. $\mathrm{PhD}$ thesis, University of Waterloo, Waterloo, ON, Canada, available online at http://hdl.handle.net/ $10012 / 2654$

28. Lemieux JM, Sudicky EA, Peltier WR, Tarasov L (2008) Dynamics of groundwater recharge and seepage over the Canadian landscape during the Wisconsinian glaciation. J Geophys Res 113:F01011. doi:10. 1029/2007JF000838

29. Lemieux JM, Sudicky EA, Peltier WR, Tarasov L (2008) Simulating the impact of glaciations on continental groundwater flow systems: 1. Relevant processes and model formulation. J Geophys Res 113:F03017. doi:10.1029/2007JF000928

30. Lemieux JM, Sudicky EA, Peltier WR, Tarasov L (2008) Simulating the impact of glaciations on continental groundwater flow systems: 2. Model application to the Wisconsinian glaciation over the Canadian landscape. J Geophys Res 113:F03018. doi:10.1029/2007JF000929

31. McIntosh JC, Walter LM (2005) Volumetrically significant recharge of Pleistocene glacial meltwaters into epicratonic basins: constraints imposed by solute mass balances. Chem Geol 222(3-4):292-309

32. McIntosh JC, Walter LM (2006) Paleowaters in silurian-devonian carbonate aquifers: geochemical evolution of groundwater in the great lakes region since the late pleistocene. Geochim Cosmochim Acta 70:2454-2479

33. McIntosh JC, Walter LM, Martini AM (2002) Pleistocene recharge to midcontinent basins: Effects on salinity structure and microbial gas generation. Geochim Cosmochim Acta 66(10):1681-1700

34. McIntosh JC, Garven G, Hanor JS (2005) Modeling variable-density fluid flow and solute transport in glaciated sedimentary basins. Eos Trans AGU 86(52), fall Meet. Suppl., Abstract H11D-1310 
35. Moeller CA, Mickelson DM, Anderson MP, Winguth C (2007) Groundwater flow beneath Late Weichselian glacier ice in Nordfjord, Norway. J Glaciol 53(180):84-90

36. Person M, Dugan B, Swenson JB, Urbano L, Stott C, Taylor J, Willett M (2003) Pleistocene hydrogeology of the Atlantic continental shelf, New England. Geol Soc Am Bull 115(11):1324-1343

37. Person M, McIntosh J, Bense V, Remenda VH (2007) Pleistocene hydrology of North America: the role of ice sheets in reorganizing groundwater flow systems. Rev Geophys 45:RG3007. doi:10.1029/ 2006RG000206

38. Piotrowski JA (1997) Subglacial groundwater flow during the last glaciation in northwestern Germany. Sediment Geol 111:217-224

39. Piotrowski JA (1997) Subglacial hydrology in north-western Germany during the last glaciation: groundwater flow, tunnel, valleys and hydrological cycles. Quat Sci Rev 16:169-185

40. Provost AM, Voss CI, Neuzil CE (1998) Glaciation and regional ground-water flow in the Fennoscandian shield; Site 94. SKI Report 96:11, Swedish Nuclear Power Inspectorate, Stockholm, Sweden

41. Raven KG, Bottomley DJ, Sweezey RA, Smedley JA, Ruttan TJ (1987) Hydrogeological characterization of the East Bull Lake research area. Tech. rep., National Hydrology Research Institute Paper No. 31, Inland Waters Directorate Series No. 160, Environment Canada, Ottawa, Canada

42. Sheppard MI, Thibault DH, Milton GM, Reid JAK, Smith PA, Steve K (1995) Characterization of a suspected terrestrial deep groundwater discharge area on the Canadian Precambrian shield. J Contam Hydrol 18(1):59-84

43. Siegel DI (1989) Geochemistry of the Cambrian-Ordovician aquifer system in the Northern Midwest, United States. U.S. Geological Survey Professional Paper 1405-D, USGS, Denver, Colorado

44. Siegel DI (1991) Evidence for dilution of deep, confined ground water by vertical recharge of isotopically heavy Pleistocene water. Geology 19(5):433-436

45. Siegel DI, Mandle RJ (1983) Isotopic evidence for glacial meltwater recharge to the Cambrian-Ordovician aquifer, North-Central United States. Quart Res 22(3):328-335

46. Stotler RL (2008) Evolution of Canadian Shield groundwaters and gases: influence of deep permafrost. $\mathrm{PhD}$ thesis, University of Waterloo, Waterloo, ON, Canada. Available online at http://hdl.handle.net/ $10012 / 4020$

47. Stotler RL, Frape SK, Ruskeeniemi T, Ahonen L, Onstott TC, Hobbs MY (2009) Hydrogeochemistry of groundwaters in and below the base of thick permafrost at Lupin, Nunavut, Canada. J Hydrol 373(1-2): 80-95. doi:10.1016/j.jhydrol.2009.04.013

48. Tarasov L, Peltier WR (1999) Impact of thermomechanical ice sheet coupling on a model of the $100 \mathrm{kyr}$ ice age cycle. J Geophys Res 104(D8):9517-9545

49. Tarasov L, Peltier WR (2002) Greenland glacial history and local geodynamic consequences. Geophys J Int 150:198-229

50. Tarasov L, Peltier WR (2004) A geophysically constrained large ensemble analysis of the deglacial history of the North American ice-sheet complex. Quat Sci Rev 23(3-4):359-388

51. Tarasov L, Peltier WR (2006) A calibrated deglacial drainage chronology for the North American continent: Evidence of an Arctic trigger for the Younger Dryas. Quat Sci Rev 25(7-8):659-688

52. Therrien R, McLaren R, Sudicky EA, Panday S (2006) HydroGeoSphere, a three-dimensional numerical model describing fully-integrated subsurface and surface flow and solute transport. Groundwater Simulations Group, Waterloo, Ontario, Canada

53. Vaikmäe R, Vallner L, Loosli HH, Blaser PC, Julliard-Tardent M (2001) Paleogroundwater of glacial origin in the Cambrian-Vendian aquifer of northern Estonia. In: Edmunds WM, Milne CJ (eds) Paleowaters in coastal Europe: evolution of groundwater since the late Pleistocene. Geological Society, London, pp 17-27, Special Publications, 189

54. van Weert FHA, van Gijssel K, Leijnse A, Boulton GS (1997) The effects of Pleistocene glaciations on the geohydrological system of Northwest Europe. J Hydrol 195(1-4):137-159

55. Vidstrand P, Wallroth T, Ericsson LO (2008) Coupled HM effects in a crystalline rock mass due to glaciation: indicative results from groundwater flow regimes and stresses from an FEM study. Bull Eng Geol Environ 67(2): 187-197. doi:10.1007/s10064-008-0123-8

56. Voss CI, Provost AM (2001) Recharge-area nuclear waste repository in southeastern Sweden-demonstration of hydrogeologic siting concepts and techniques. SKI Report 01:44, Swedish Nuclear Power Inspectorate, Stockholm, Sweden

57. Weaver TR, Frape SK, Cherry JA (1995) Recent cross-formational fluid flow and mixing in the shallow Michigan Basin. Geol Soc Am Bull 107(6):697-707

58. Wheeler JO, Hoffman PF, Cardand KD, Davidson A, Sanford BV, Okulitch AV, Roest WR (1997) Geological map of Canada, Map D1860A. Geological Survey of Canada, Ottawa, Canada 